\title{
PENDUGAAN UMUR SIMPAN MINUMAN INSTAN TEH KOMBUCHA MENGGUNAKAN PENDEKATAN KADAR AIR KRITIS DENGAN METODE ACCELERATED SHELF LIFE TEST (ASLT)
}

\author{
Risa Meutia Fiana dan Cesar Welya Refdi \\ Prodi Teknologi Hasil Pertanian Fakultas Teknologi Pertanian Universitas Andalas \\ Email: risameutia@ymail.com
}

\begin{abstract}
ABSTRAK
Pendugaan Umur simpan minuman instan teh kombucha dilihat berdasarkan kadar air kritis menggunakan pendekatan ASLT (Accelerated Shelf Life Test) dengan perhitungan menggunakan Model Labuza. Selama penyimpanan sampel ditimbang secara periodik (2 hari sekali selama 40 hari) hingga mencapai berat konstan. Sampel yang telah mencapai berat konstan dianalisa kadar air dan vitamin C. Kesimpulan yang dapat diambil dari penelitian ini yaitu umur simpan minuman instan teh kombucha dengan menggunakan pendekatan kadar air kritis dengan metode ASLT (Accelerated Shelf Life Test) pada suhu $30^{\circ} \mathrm{C}$ dan RH penyimpanan $75 \%$ yaitu 503 hari menggunakan kemasan LDPE (Linear Low Density Polyethy-lene).

Kata kunci-kadar air kritis; minuman instan; teh kombucha; umur simpan
\end{abstract}

\section{PENDAHULUAN}

Semenjak zaman dahulu, manusia selalu berusaha untuk tetap sehat. Seiring perkembangan zaman kesadaran masyarakat akan hidup semakin meningkat. Hal tersebut terbukti dengan kebiasaan masyarakat moderen untuk mengkonsumsi food suplemen. Food suplemen yang ada juga bervariasi, baik yang telah tersedia dalam bentuk tablet atau kapsul (yang dibuat secara modren) ataupun yangdiolah secara tradisional yang tidak mengandung bahan kimia buatan. Naland (2008) menjelaskan, bahwa salah satu minuman yang dapat dikatakan sebagai food suplemen adalah teh kombucha. Mengenai khasiat dari teh kombucha telah banyak para ahli mengakuinya. Salah satunya adalah sebagai antioksidan.

Kombucha merupakan minuman hasil fermentasi teh dan gula dengan menggunakan kultur kombucha (Naland, 2008). Dijelaskan lebih lanjut oleh (Guntehr, 1995), kombuca merupakan minuman tradisional berasal dari Asia Timur yang terbentuk karena adanya simbiosis antara bakteri dan ragi. Kombucha dikenal oleh masyarakat Indonesia sebagai jamur teh yang merupakan campuran kultur bakteri dan khamir sehingga memiliki rasa asam dan terbentuk lapisan nata (Hidayat., Mardiana dan Sri, 2006). Kombucha dapat dijadikan minuman instan, supaya lebih mudah dan efesien ketika dikonsumsi.

Minuman instan adalah produk olahan dari pangan yang memiliki bentuk serbuk, larut di dalam air dan mudah dalam menyajikannya (Meutia, R, dkk., 2016). Minuman serbuk instan mudah untuk dikonsumsi dengan cara menambahkan air panas atau air dingin saja. Minuman instan teh kombucha merupakan minuman berbentuk serbuk yang berbahan baku teh kombucha menggunakan bahan pengisi seperti maltodekstrin. Penggunaan maltodekstrin yang optimal dalam pembuatan minuman instan teh kombucha sebanyak 20\% (Meutia, R, dkk., 2016). Maltodekstrin dapat melapisi komponen dari flavor, meningkatkan jumlah total padatan, dan mengurangi kerusakan dari bahan yang dikeringkan (Oktaviana, 2012).

Informasi umur simpan menurut undang-undang tahun 1996 dan peraturan pemerintahan nomor 69 tahun tentang label iklan dan pangan merupakan hal yang wajib dicantumkan dalam produk pangan. Informasi umur simpan berguna sebagai informasi untuk menentukan kelayakan suatu pangan untuk dikonsumsi untuk menghindari hal-hal yang tidak diinginkan seperti keracunan makanan. Pencantuman umur simpan sangat berguna untuk produsen, konsumen dan distributor untuk mengetahui mutu pangan tersebut untuk dikonsumsi. Umur simpan produk adalah selang waktu yang menunjukan antara produksi awal hingga batas akhir produk dapat diterima oleh pasar sesuai dengan mutu yang dijanjikan. Umur simpan produk adalah selang waktu antara produksi sampai dikonsumsi dimana sifat produk masih dapat diterima baik rasa, penampakan, organoleptik dan nilai gizi (Arpah, 2001). 
Pemilihan metode kadarluarsa yang digunakan untuk produk pangan harus sesuai dengan sifat pangan tersebut. Robert, 1992 cit Arpah (2001) mengelompokan pangan berdasarkan perubahan kadar air selama penyimpanan menjadi dua yaitu pertama kelompok pangan yang menyerap air selama penyimpana dan kelompok kedua adalah kelompok pangan yang kehilangan uap air selama penyimpanan.

Minuman instan teh kombucha merupakan bahan pangan yang bersifat higroskopis (mudah menyerap air). Metode yang tepat dalam penentuan umur simpan untuk produk yang bersifat higroskopis adalah dengan menggunakan kadar air kritis (Ensin dan Robinson, 2011 cit Mustafida, dkk., 2015). Metode kadar air kritis merupakan metode yang diterapkan dimana perubahan kadar air menjadi kriteria kadarluarsa (Puji dan Arpah, 2003).

Penetapan umur simpan dengan menggunakan kadar air kritis terdapat berbagai metode, salah satu metode yang dapat digunakan adalah pendekatan ASLT (Accelerated Shelf Life Test). ASLT merupakan metode yang digunakan untuk menentukan umur simpan dengan lingkungan yang terkontrol seperti kelembabpan dari lingkungan (Arpah, 2001).

\section{METODOLOGI PENELITIAN}

\section{A. Lokasi dan Waktu Penelitian}

Penelitian telah dilaksanakan di laboratorium Bioteknologi dan Mikrobilogi Teknologi Hasil Pertanian, Laboratorium Instrumen Fakultas Teknologi Pertanian, Laboratorium Kimia dan Biokimia Hasil Pertanian Fakultas teknologi Pertanian dan Laboratorium Sedian Tablet Fakultas Farmasi pada bulan April sampai dengan Sepetember 2017.

\section{B. Bahan dan Alat}

Bahan baku minuman instan teh kombucha yang digunakan dalam penelitian ini yaitu gula merk gulaku, teh merek sariwangi maltodekstrin, plastik LDPE dan bibit kombucha berumur 7 hari. Pendugaan umur simpan menggukana bahan kimia $\mathrm{NaOH}, \mathrm{MgCl}_{2}, \mathrm{NaCl}, \mathrm{KCl}$ dan $\mathrm{K}_{2} \mathrm{Cr}_{2} \mathrm{O}_{7}$, sedangkan untuk pengujian menggunakan bahan kimia iodium dan aquades. Alat yang digunakan dalam penelitian ini ini yaitu spray drier, magnetic strirer, gelas piala, gelas ukur, batang pengaduk, timbangan digital, erlemeyer, buret, pipet tetes, oven, toples kedap udara dan buret.

\section{Metodelogi Penelitian}

Penelitian ini dilakukan secara deksriptif dimana pendugaan umur simpan dihitung dengan persamaan Labuza dan yang menjadi titik kritis pada minuman instan teh kombucha yaitu kadar air selama penyimpanan.

\section{Prosedur Percobaan}

1. Pembuatan Teh Kombuca (Meutia, R,dkk., 2016)

Air sebanyak 1 liter didihkan setelah itu ditambahkan gula sebanyak 100 gram dan 4 sachet teh celup kemudian dibiarkan selama 15 menit agar gula dan teh terlarut. Suhu larutan teh manis dibiarkan menurun hingga suhu $25-27^{\circ} \mathrm{C}$. Bibit kombucha diinokulasikan ke dalam larutan teh manis yang telah mencapai $25-27^{\circ} \mathrm{C}$. Wadah ditutup dengan kain bersih dan diikat dengan karet. Kain penutup ditutup rapat dan kencang. Teh kombucha difermentasi selama 7 hari dengan suhu penyimpanan $25-27^{\circ} \mathrm{C}$ dan dalam keadaan gelap.

\section{Pembuatan Minuman Instan Teh Kombucha (Meutia, R, dkk., 2016)}

Pembuatan minuman instan teh kombucha menggunakan alat spray drier. Teh kombucha yang telah di panen disaring terlebih dahulu. Tambahkan maltodekstrin sebanyak $20 \%$ ke dalam $250 \mathrm{ml}$ teh kombucha. Homogenkan maltodekstrin dan teh kombuca dengan cara diaduk dengan menggunakan magnetik strirer selama 5 menit. Lakukan spray drier dengan suhu inlet $80^{\circ} \mathrm{C}$ dan suhu outlet $100^{\circ} \mathrm{C}$. Minuman teh instan kombucha disimpan dalam kemasan alumunium.

\section{Pendugaan Umur Simpan Metode ASLT (Accelerated Shelf Life Tes)}

Metode ASLT yang digunakan yaitu mempercepat kerusakan produk dengankondisi penyimpanan yang mempercepat peningkatan kadar air dengan menyimpan minuman instan teh 
kombucha ke dalam toples yang berisi larutan garam jenuh yang telah dipersiapkan terlebih dahulu sebelum diisi sampel (minuman instan teh kombucha). Sampel yang telah ditimbang dimasukan ke dalam toples yang berisi larutan garam jenuh (Puji dan Arpah, 2003). Selama penyimpanan sampel ditimbang secara periodik (2 hari sekali selama 40 hari) hingga mencapai berat konstan (Mustafida, dkk., 2015)). Sampel yang telah mencapai berat konstan dianalisa kadar air, aktivitas air, dan kadar vitamin C. Tabel 1. merupakan komposisi larutan garam jenuh untuk menghasilkan kondisi aktivitas air (Aw) yang diinginkan.

Tabel 1. Komposisi jumlah garam (gr) dengan jumlah air (ml) dalam pembuatan garam jenuh

\begin{tabular}{cccc}
\hline Jenis Garam & Aw & Jumlah Garam (gr) & Jumlah Air (ml) \\
\hline $\mathrm{NaOH}$ & 0,06 & 150 & 85 \\
$\mathrm{MgCl}_{2}$ & 0,32 & 200 & 25 \\
$\mathrm{NaCl}$ & 0,75 & 200 & 60 \\
$\mathrm{KCl}$ & 0,84 & 200 & 80 \\
$\mathrm{~K}_{2} \mathrm{Cr}_{2} \mathrm{O}_{7}$ & 0,95 & 250 & 50 \\
\hline
\end{tabular}

Sumber: Puji dan Arpah, 2003.

Pendugaan umur simpan dihitung dengan persamaan Labuza, sebagai berikut:

$t=\frac{\ln \left[\frac{m_{e}-m_{i}}{m_{e}-m_{c}}\right]}{\frac{k}{x} \frac{A}{W_{s}} \frac{P_{o}}{b}}$

Keterangan:

t $\quad$ : Umur simpan produk (hari)

$\mathrm{Me} \quad$ : Kadar air kesetimbangan produk

Mi : Kadar air awal produk

Mc : Kadar air kritis produk

$\mathrm{K} / \mathrm{x} \quad$ : Nilai permeabilitas uap air

A : Luas kemasan

Ws : Berat kering produk

Po : Tekanan uap air jenuh

b : Slope kurva sorpsi ishotermis produk

\section{E. Prosedur Pengamatan}

Parameter yang diamati pada Minuman instan teh kombucha dengan menggunakan metode ASLT dengan persamaan Labuza yaitu:

1. Kadar Air Awal Produk (Mi) Menggunakan Metode Oven (Muchtadi, 2010)

2. Kadar Air kritis (Mc)

Kadar air kritis adalah kadar air dimana minuman instan teh kombucha telah membentuk gumpalan. Produk disimpan pada suhu $35^{\circ} \mathrm{C}$ dengan Aw 0,84 kumudian produk diamati setiap jam hingga menggumpal (Anom, M dan Komang, 2008). Produk yang telah menggumpal diukur kadar air dengan metode oven.

3. Kadar Air keseimbangan (Me)

Larutan garam jenuh pada Tabel 1. dipersiapkan terlebih dahulu. Sampel (minuman instan teh kombucha yang telah dikemas) ditimbang beratnya. Sampel diletakan didalam toples tanpa menyentuh larutan garam jenuh. Selama penyimpanan sampel ditimbang secara periodik (2 hari sekali selama 40 hari) hingga mencapai berat konstan. Sampel yang telah mencapai berat konstan dianalisa kadar airnya (Anom, M dan Komang, 2008).

4. Slope Kurva Isotermik (b)

Slope kurva isotermis diperoleh dengan cara mengambarakan hubungan antara kadar air keseimbangan sampel dengan aktivitas air (Aw) ruang tempat penyimpanan (toples yang berisi garam jenuh (Anom, M dan Komang, 2008 dengan modifikasi). 
5. Berat Kering Produk (b)

Berat kering produk merupakan hasil kali berat sampel awal produk dikalikan dengan total padatan (Puji dan Arpah, 2003).

6. Tekanan uap air jenuh (Po)

Penentuan tekanan uap air jenuh dapat dilihat dengan menggunakan tabel hubungan antara aktivitas air dengan suhu.

\section{F. Parameter pendukung (Kadar Vitamin C, Metode Titrasi Iodium, (Muchtadi, 2010))}

Pengukuran kadar vitamnin C menggunakan metode titrasi iodium. Timbang 20-30 gram sampel kemudian dimasukan ke dalam labu takar $100 \mathrm{ml}$, aqudes ditambakan sampai tanda tera. Setelah itu dilakukan penyaringan dengan menggunakan krus Gooch atau dengan menggunakan sentrifuse untuk memisahkan padatan. Filtrat dipipet sebanyak $5 \mathrm{ml}$ kemudian ditambahkan $2 \mathrm{ml}$ larutan amilum $1 \%$. Filtrat selanjutnya ditirasi dengan larutan yodium $0,01 \mathrm{~N}$. Kadar vitamin $\mathrm{C}$ dihitung dengan

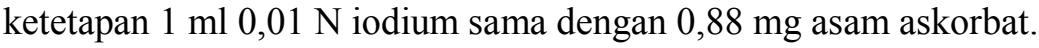

\section{HASIL DAN PEMBAHASAN}

Minuman instan teh kombucha merupakan bahan pangan yang bersifat higroskopis (mudah menyerap air). Metode yang tepat dalam penentuan umur simpan untuk produk yang bersifat higroskopis adalah dengan menggunakan kadar air kritis (Ensin dan Robinson, 2011 cit Mustafida, dkk., 2015). Metode kadar air kritis merupakan metode yang diterapkan dimana perubahan kadar air menjadi kriteria kadarluarsa (Puji dan Arpah, 2003).

Metode yang digunakan dalam penentuan minuman instan teh kombucha yaituASLT (Accelerated Shelf Life Test). ASLT merupakan penyimpanan contoh dalam menetapkan kadarluarsa pangan secara menyimpan dengan kondisi yang mempercepat kerusakan produk tersebut Kondisi penyimpanan yang bisa digunakan untuk mempercepat kerusakan produk yaitu kadar air kritis dan suhu penyimpanan (Robert, 1992 cit Arpah, 2001).

Minuman Instan teh kombucha terlebih dahulu dianalisis vitamin C. Tujuan analisa bahan baku ini adalah untuk mengetahui kerusakan kandungan yang ada pada minuman instan teh kombucha selama penyimpanan hingga mengalami kerusakan. Kadar vitamin $\mathrm{C}$ awal pada teh kombucha yaitu $665,27 \mathrm{mg} / 100 \mathrm{gr}$. Indikator kerusakan minuman instan teh kombuca adalah minuman instan teh kombucha yang telah dikemas mengalami penggumpalan dan telah mencapai kadar air keseimbangan.

\section{A. Kurva Sorpsi Isotermis}

Kurva sorpsi isotermis menggambarkan hubungan antara kadar air keseimbangan minuman instan teh kombucha dalam berat kering yang disimpan didalam suatu ruangan yang kondisi aktivitas air telah diatur. Minuman instan teh kombucha dilakukan penyimpanan pada 5 kondisi Aw setiap 2 hari sekali ditimbang bertanya sampai konstan. Tabel 2. menunjukan hasil kadar air keseimbangan minuman instan teh kombucha.

Tabel 2. Kadar Air Keseimbangan pada Berbagai Aw

\begin{tabular}{lcc}
\hline Garam Jenuh & Aw & $\begin{array}{c}\text { Kadar Air Keseimbangan } \\
\text { ( \% berat kering) }\end{array}$ \\
\hline $\mathrm{NaOH}$ & 0,06 & 4,8372 \\
$\mathrm{MgCl}_{2}$ & 0,32 & 5,4342 \\
$\mathrm{NaCl}$ & 0,75 & 6,7818 \\
$\mathrm{KCl}$ & 0,85 & 6,8997 \\
$\mathrm{~K}_{2} \mathrm{Cr}_{2} \mathrm{O}_{7}$ & 0,95 & 8,3328 \\
\hline
\end{tabular}

Kadar air kesimbangan bahan adalah kadar air dimana suatu bahan pangan akan mencapai berat konstannya (Fitria, 2007). Berat bahan pangan dikatakan onstan apabila berat bahan pangan yang ditimbang sebanyak tiga kali berturut-turut idak lebih dari $20 \mathrm{mg} / \mathrm{g}$ pada $\mathrm{RH} \leq 90 \%$ dan tidak lebih dari $10 \mathrm{mg} / \mathrm{g}$ pada kondisi penyimpanan $\mathrm{RH} \leq 90 \%$. Berdasarkan kurva sorpsi isotermis diatas diperoleh persamaan garis $\mathrm{Y}=0,845 \mathrm{x}+3,920$ maka berdasarkan persamaan tersebut maka diperolleh nilai b (slope) sebesar 0,845. Pada Gambar 1, menunjukan slope kurva sorpsi isotermis. 


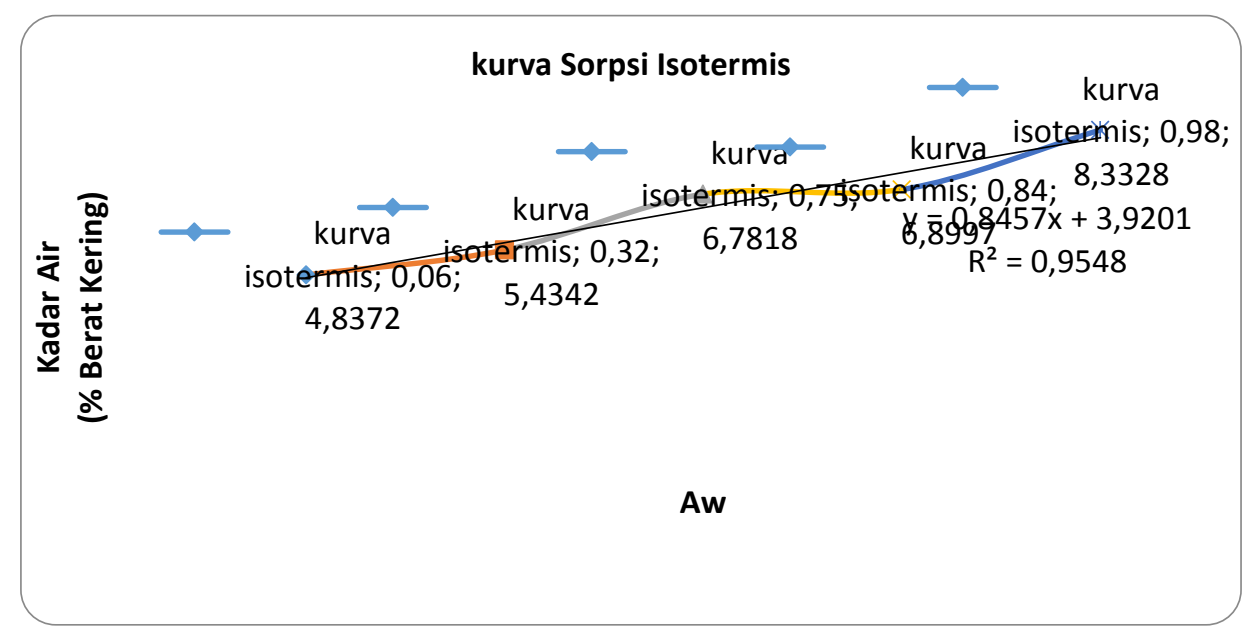

Gambar 1. Kurva Sorpsi Isotermis Minuman Instan Teh Kombucha Umur Simpan Minuman Instan Teh Kombucha dengan Metode Labuza

Minuman instan teh kombucha disimpan selama 40 hari, selama 2 hari sekali dilakukan penimbangan minuman instan teh kombucha hingga mencapai berat konstan. Berdasarkan persamaan dari Labuza dalam menentukan umur simpan suatu produk maka diperlukan faktor-faktor yaitu kadar air awal produk (Mi), kadar air kritis (Mc), Kadar air keseimbangan (Me), Slope kurva isorpsi isotermis (b), berat kering produk (Ws), tekanan uap air jenuh (Po), Luas kemasan (A) dan permeabilitas uap air dari kemasan $(\mathrm{k} / \mathrm{X})$. Kemasan yamg digunakan pada penyimpanan minuman instan tek kombucha ini adaah kemasan LDPE (Linear Low Density Polyethy-lene) dengan luas kemasan $24 \times 10^{4} \mathrm{~m}^{2}$ dengan permeabilitas uap air sebesar $0,47 \mathrm{~g} / \mathrm{m}^{2}$. Perkiraan umur simpan minuman instan teh kombucha menggunakan persaamaan Labuza. Tabel 3. Merupakan faktor-faktor yang digunakan sebagai parameter untuk menentukan umur simpan minuman instan teh kombucha.

Tabel 3. Parameter Minuman Instan Teh Kombucha pada Suhu $30{ }^{\circ} \mathrm{C}$ RH 75\%

\begin{tabular}{lcc}
\hline \multicolumn{1}{c}{ Parameter } & Satuan & Hasil Analisa \\
\hline Kadar air awal produk (Mi) & $\%$ & 2,0433 \\
Kadar air kritis (Mc) & $\%$ & 6,7818 \\
Kadar air keseimbangan (Me) & $\%$ & 6,0911 \\
Berat kering produk (Ws) & $\mathrm{G}$ & 2,4636 \\
Tekanan uap air jenuh (Po) & $\mathrm{mmHg}$ & 31,824 \\
Luas kemasan (A) & $\mathrm{m}^{2}$ & $24 \times 10^{4}$ \\
permeabilitas uap air dari kemasan (k/x) & $\mathrm{g} / \mathrm{m}^{2} \mathrm{hr} \cdot \mathrm{mmHg}$ & 0,47 \\
Slope kurva isorpsi isotermis (b) & - & 0,845 \\
\hline
\end{tabular}

Sumber: Labuza (1982)

Data pada Tabel 3, disubstitusikan ke dalam persamaan Labuza untuk memperkiraan umur simpan dari minuman instan teh kombucha. Berdasarkan persamaan Labuza dengan kondisi penyimpanan pada suhu $30^{\circ} \mathrm{C}$ dengan nilai $\mathrm{RH} 75 \%$ maka diperoleh umur simpan dari minuman instan teh kombucha 503,87 hari dan digenapkan menjadi 503 hari. Beberapa hal yang harus diperhatikan pada pengemasan minuman instan teh kombucha yaitu waktu kontak minuman instan teh kombucha. Jika waktu kontak pada saat pengemasan lama akan menyebabkan tingginya kadar air awal minuman instan tek kombucha. Kadar air awal minuman instan teh kombucha ini dapat menyebabkan berkurangnya umur simpan dari minuman instan teh kombucha. Hal-hal yang harus diperhatikan pada saat melakukan pengemasan adalah waktu kontak antara produk yang telah selesai diproduksi (freshly processed seasoning) terhadap kondisi lingkungan pengemasan, dan bahan yang digunakan untuk mengemas juga harus sesuai dengan standar produk (Ensin and Robinson, 2011 Mustafida, dkk., 2015). Karakteristik jenis kemasan akan mempengaruhi umur simpan minuman instan teh kombucha selama pendistribusian. Umur simpan minuman instan teh kombucha dapat diperahankan dengan mengatur kondisi penyimpanan produk.Kondisi penyimpanan produk pada saat diproduksi yang harus diperhatikan antara 
lain RH ruang-an maupun suhu ruangan dipertahankan stabil atau tidak fluktuatif selama proses penyimpanan berlangsung (Budijanto,S dkk., 2010).

\section{B. Kandungan Vitamin C Minuman Instan Teh Kombucha yang Telah menggalami kerusakan}

Kandungan vitamin $\mathrm{C}$ merupakan titik kritis dari minuman instan teh kombucha. Minuman instan teh kombucha yang telah mengalami penggumpalan merupakan salah satu kriteria tidak layak untuk dikonsumsi. Selama penyimpanan minuman instan teh kombucha dalam menentukan kadar air keseimbangan produk didapatkan produk mengalami penggumpalan. Penggumpalan terjadi karena uap air diruang penyimpanan yang telah diatur RH berdifusi kedalam kemasan. Perbedaan tekanan uap air akan menyebakna terjadinya perpindahan antara tekanan uap air yang bertekanan tinggi ke tekanan uap air yang rendah (Sahzadi,dkk., 2005 dalam Musdalifa, dkk.,2015). Produk yang telah mengalami penggumpalan dilakukan analisis kandungannya meliputi kadar vitamin C. Kadar vitamin C minuman instan teh kombucha yang telah mengalami penggumpalan pada RH $75 \%$ yaitu 496,72 mg/100gr. Minuman instan teh kombucha pada saat telah mengalami penggumpalan mengalami penurunan kandungan Vitamin C. Penggumpalan minuman instan teh kombucha ini disebabkan oleh permeabilitas uap air dan gas yang berada di lingkungan penyimpanan. Oksidasi yang terjadi pada minuman instan teh kombucha yang telah mengalami kerusakan disebabkan oleh oksidasi vitamin $\mathrm{C}$ secara spontan. Oksidasi vitamin $\mathrm{C}$ secara spontan dipengaruhi oleh udara yang berada di sekitar (Helmiyesi, dkk., 2008).Uap air dan gas yang masuk ke dalam pengemasan menyebabkan vitamin $\mathrm{C}$ mengalami oksidasi sehingga kadar Vitamin C berkurang selama penyimpanan.

\section{KESIMPULAN}

Umur simpan minuman instan teh kombucha dengan menggunakan pendekatan kadar air kritis dengan metode ASLT (Accelerated Shelf Life Test) pada suhu $30 \mathrm{C}$ dan RH penyimpanan $75 \%$ yaitu 503 hari menggunakan kemasan LDPE. Minuman instan teh kombucha yang telah melewati umur simpan dapat dilihat secara visual langsung yaitu telah mengalami penggumpalan. Penurunan mutu komposisi kimia juga terjadi pada minuman instan yang telah melewati umur simpan. Penurunan mutu ini terlihat produk yang mengalami penggumpalan dan kandungan vitamin $\mathrm{C}$ yang mengalami penurunan

\section{UCAPAN TERIMA KASIH}

Penulis mengucapkan terima kasih kepada Fakultas Teknologi Pertanian, melalui skim DIPAFakultas selaku pihak yang memberikan dana pada penelitian ini sehingga penelitian ini dapat diaksanakan.

\section{DAFTAR PUSTAKA}

Anom, M dan Komang, 2008. Penentuan Masa Kadarluarsa Renginang dengan Menggunakan Model Labuza. Jurnal Agrotekno Volume 14, Nomor 1 (ISSN 0853-64 14).

Arpah. 2001. Penetapan Kadarluarsa Pangan. Departemen Teknologi Pangan dan Gizi Fakultas Teknologi Pertanian Institut Pertanian Bogor.

Budijanto, S., Azis, B., Beti, E dan Wita, M. 2010. Penentuan Umur Simpan Seasoning Menggunakan Metode Accerelated Shelf Life Test (ASLT) dengan Pendekatan Air Kritis. Jurnal Teknologi Pertanian Volume 11 No.2.

Fitria, M. (2007). Pendugaan Umur Simpan Produk Biskuit dengan Metode Akselerasi Berdasarkan Pendekatan Kadar Air Kritis. Departemen Ilmu dan Teknologi Pangan. Institut Pertanian Bogor.

Gunther, F. 1995. Kombucha-Helathy Beverage and Natural Remedy from th Far East : Its Correct Preparation and Use. Ennstahler Gesellschaaft GmbH and Co KG. German.

Helmiyesi, Hastuti, R. B., Prihastanti, E. 2008. Pengaruh Lama Penyimpanan Terhadap Kadar Gula dan Vitamin C pada Buah Jeruk Siam (Citrus nobilis var. microcarpa).Buletin Anatomi dan Fisiologi Volume XVI, Nomor 2, Oktober 2008.

Hidayat, N., Mardiana dan Sri S.2006. Mikrobiologi Industri. ANDI. Yogyakarta. 
Meutia, R., Wenny, S dan Alfi, A. 2016. Pengaruh Konsentrasi Maltodekstrin terhadap Minuman Instan Teh Kombuca. Jurnal Teknologi Pertanian Universitas Andalas Volume 2 Nomor 2 Halaman 18.

Mustafidah, C dan Simon, B. 2015. Umur Simpan Minuman Serbuk Berserat dari Tepung porang (Amorpophallusorcophillus) dan Karagenan Melalui Pendekatan Kadar Air Kritis. Jurnal Pangan dan Agroindustri Volume 3 Nomor 2 Halaman 650-660 April 2015.

Naland, H. 2008. Kombucha Teh dengan Seribu Khasiat. Agromedia Pustaka. Jakarta.

Oktaviana, D. 2012. Kombinasi Maltodekstrin dan Suhu Pemanasan Terhadap Kualitas Minuman Serbuk Instan Belimbing Wuluh (Avverhoa bilimbi Linn.).Skripsi. UAJY. Yogyakarta.

Puji, W dan Arpah. 2003. Penetapan Kadarluarsa Produk Industri Kecil Pangan. Departemen Teknologi Pangan dan Gizi Fakultas Teknologi Pertanian Institut Pertanian Bogor. 